Article

\title{
Osseointegration of Antimicrobial Acrylic Bone Cements Modified with Graphene Oxide and Chitosan
}

\author{
Mayra Eliana Valencia Zapata ${ }^{1}\left(\mathbb{0}\right.$, José Herminsul Mina Hernandez ${ }^{1, *} *$, \\ Carlos David Grande Tovar ${ }^{2}$ D , Carlos Humberto Valencia Llano ${ }^{3}$, Blanca Vázquez-Lasa ${ }^{4,5}, * \mathbb{D}$, \\ Julio San Román ${ }^{4,5}$ and Luis Rojo ${ }^{4,5}$ (D) \\ 1 Grupo de Materiales Compuestos, Escuela de Ingeniería de Materiales, Universidad del Valle, \\ Calle 13 \# 100-00, Cali 76001, Colombia; valencia.mayra@correounivalle.edu.co \\ 2 Grupo de Investigación de Fotoquímica y Fotobiología, Universidad del Atlántico, \\ Carrera 30 Número 8-49 Puerto Colombia, Atlántico 081008, Colombia; \\ carlosgrande@mail.uniatlantico.edu.co \\ 3 Grupo Biomateriales Dentales, Escuela de Odontología, Universidad del Valle, Calle 4B No. 36-00, \\ Cali 76001, Colombia; carlos.humberto.valencia@correounivalle.edu.co \\ 4 Instituto de Ciencia y Tecnología de Polímeros, ICTP-CSIC, C/Juan de la Cierva 3, 28006 Madrid, Spain; \\ jsroman@ictp.csic.es (J.S.R.); rojodelolmo@ictp.csic.es (L.R.) \\ 5 Consorcio Centro de Investigación Biomédica en Red, CIBER-BBN, Instituto de Salud Carlos III, \\ C/Monforte de Lemos 3-5, 1128029 Pabellón, Spain \\ * Correspondence: jose.mina@correounivalle.edu.co (J.H.M.H.); bvazquez@ictp.csic.es (B.V.-L.); \\ Tel.: +57-2-3302436 (J.H.M.H.); +34-915622900 (B.V.-L.)
}

Received: 29 July 2020; Accepted: 13 September 2020; Published: 18 September 2020

\begin{abstract}
Acrylic bone cement (ABC) is one of the most used materials in orthopedic surgery, mainly for the fixation of orthopedic implants to the bone. However, ABCs usually present lack of biological activity and osseointegration capacity that leads to loosening of the prosthesis. This work reports the effect of introducing graphene oxide (GO) and chitosan (CS), separately or together, in the $\mathrm{ABC}$ formulation on setting performance, mechanical behavior, and biological properties. Introduction of both $\mathrm{CS}$ and $\mathrm{GO}$ to the $\mathrm{ABC}$ decreased the maximum temperature by $21 \%$ and increased the antibacterial activity against Escherichia coli by $87 \%$, while introduction of only CS decreased bending strength by $32 \%$. The results of cell viability and cell adhesion tests showed in vitro biocompatibility. The in vivo response was investigated using both subdermal and bone parietal implantations in Wistar rats. Modified ABCs showed absence of immune response, as confirmed by a normal inflammatory response in Wistar rat subdermal implantation. The results of the parietal bone implantation showed that the addition of CS and GO together allowed a near total healing bone-cement interface, as observed in the micrographic analysis. The overall results support the great potential of the modified ABCs for application in orthopedic surgery mainly in those cases where osseointegration is required.
\end{abstract}

Keywords: acrylic bone cement; antibacterial activity; biocompatibility; cell viability; chitosan; graphene oxide; nanocomposite; osseointegration

\section{Introduction}

Acrylic bone cement $(\mathrm{ABC})$ is one of the most widely used materials in orthopedic surgery, and the gold standard for the fixation of orthopedic implants to bone [1]. Since ABCs are the anchoring point at the implant-bone interface, they are important for load transfer [2,3]. The main advantage of their use is a fast primary fixation with a subsequent efficient patient recovery [4]. 
The bone-cement interface plays a key role for the longevity of the implanted prostheses [5]. Due to this, in recent decades there has been a strong effort to overcome one of the biggest problems associated with $\mathrm{ABCs}$, which is the lack of biological activity [6,7] and osseointegration [2], thus promoting $A B C$ function based on mechanical interlocking with bone rather than adhesive chemical bonding to form a stable cement-bone interface [8]. Moreover, bone necrosis produced by high exothermic temperatures during the polymerization reaction and the susceptibility of some pathogenic bacteria $[9,10]$ generated premature failure [7], increasing the patient complications and leading to additional interventions what is safety risky for the patient [11-13].

Bioactive fillers such as hydroxyapatite and tricalcium phosphate have been added to overcome the low prosthesis biological performance and promote direct bone apposition rather than encapsulation of the implant by fibrous tissue [14-19]. This bioactive filler addition promoted bone growth based on strong chemical interactions between cement and bone [2,20]. However, some bioactive fillers make the cement more brittle and additional modifications on the polymeric matrix are need in order to increase ductility but at expense of decreasing the modulus [12].

The presence of biodegradable substances in $A B C$ facilitates the replacement and growth of new bone inside the cement in the pores produced by hydrolytic and enzymatic degradation in the biological medium and improves mechanical anchorage [21,22]. However, high porosity percentages in the cement produce a significant loss of mechanical properties, which is inadequate for orthopedic applications [20].

Chitosan (CS) is a linear and semi-crystalline polysaccharide consisting of $\beta-(1 \rightarrow 4)-N$-acetyl-D -glucosamine and $\beta$-(1 $\rightarrow 4)$-D-glucosamine units [22] widely used in bone regeneration due to its non-toxic, non-allergenic and non-immunogenic properties [23,24]. Moreover, it is mucoadhesive, biocompatible, biodegradable [25], bioactive [23], and osteoconductive, with a capacity to mimic the extracellular matrix due to the glycosaminoglycans (GAGs) similar structure $[24,26]$. Chitosan introduction to different biomaterials also provides very convenient antimicrobial properties in biomedical applications [24,27-30]. However, the high water affinity intrinsic property of the polysaccharide produces a serious limitation due to poor mechanical properties compared to the natural bones $[22,26]$.

Antimicrobial fillers, such as low concentrations of graphene oxide (GO) incorporated in ABCs are interesting to promote asepsis and mechanical reinforcement to joint prostheses [7,31]. GO can be dispersed in both aqueous and organic solvents [32], and under certain conditions it can be considered biocompatible [33] and antimicrobial [34]. In addition, it has been demonstrated that GO improves the viability and osteogenic differentiation of human bone marrow mesenchymal stem cells [35] and can be biodegraded by neutrophils [36], macrophages [37] and enzymes [33,38], suggesting its prospective for biomedical applications $[39,40]$.

In a previous study [31], we presented the physicochemical, thermal, mechanical, and in vitro biological characterization of novel ABCs modified with CS and GO. In the present work, new research results on material setting and bending properties are reported. In addition, new in vitro assays and in vivo experiments are addressed to confirm the biocompatibility and osseointegration of the developed $\mathrm{ABC}$ s in the presence of cells and tissues. In particular, in vitro assays of the ABCs in the presence of human osteoblasts (HOb) and Gramm-negative bacteria (E. coli) are presented and the in vivo response of the $\mathrm{ABCs}$ implanted in subdermal and parietal bone tissues evaluated. The results indicate a positive synergy between CS and GO on parameters such as maximum polymerization temperature, antimicrobial activity, bioactivity, and osseointegration of $\mathrm{ABCs}$ demonstrating applicability in tissue engineering. Thus, it is the first report of using biodegradable and antimicrobial fillers such as GO and CS biopolymer in $\mathrm{ABC}$ formulations confirming the absence of immune response in Wistar rats' subdermal implantations and a practically total healing interface between bone and ACB. 


\section{Materials and Methods}

\subsection{Materials}

The solid phase (SP) consisted of poly(methyl methacrylate) (PMMA) beads (New Stetic S.A., Medellin, Colombia), barium sulfate $\left(\mathrm{BaSO}_{4}\right)$ (Alfa Aesar, Tewksbury, MA, USA), CS from shrimp shells $\left(\mathrm{M}_{\mathrm{w}}=190-310 \mathrm{~kg} / \mathrm{mol}\right.$ and deacetylation degree (DD) of 88\%) and benzoyl peroxide (BPO) (Sigma-Aldrich, Palo Alto, CA, USA). The liquid phase (LP) was composed of methyl methacrylate (MMA), 2-(diethylamino) ethyl acrylate (DEAEA), 2-(diethylamino) ethyl methacrylate (DEAEM) (Sigma-Aldrich, Palo Alto, CA, USA), N,N-dimethyl $p$-toluidine (DMPT), (Merck, Burlington, MA, USA) and GO nanosheets synthesized by the modified Hummers method (thickness $<30$ nm, average size of $400 \mathrm{~nm}$ and interlaminar distance of $7.953 \AA$ [31]).

\subsection{Preparation of Bone Cements}

Four ABC formulations were prepared (Table 1). All formulations had a solid/liquid ratio $(\mathrm{S}: \mathrm{L})=2$. Before manual mixing of the SP and the LP, both phases were conditioned at $23 \pm 2{ }^{\circ} \mathrm{C}$ for approximately $2 \mathrm{~h}$. The LP consisted of the monomer MMA, a 50:50 weight ratio of DEAEA and DEAEM, and DMPT, as an activator. Additionally, $\mathrm{BaSO}_{4}$, the radiopaque agent for cement radiological monitoring, was added in the SP to the PMMA beads and BPO as radical initiator.

Table 1. Composition percentage $(\% w / w)$ of the Solid Phase (SP) and Liquid Phase (LP) of the ABCs formulations.

\begin{tabular}{ccccccccc}
\hline \multirow{2}{*}{ Formulation } & \multicolumn{9}{c}{ SP } & \multicolumn{5}{c}{ LP } \\
\cline { 2 - 9 } & PMMA BaSO $_{4}$ & BPO & CS & MMA & Comonomers & DMPT & GO \\
\hline Control ABC & 88 & 10 & 2 & 0 & 95.5 & 2 & 2.5 & 0 \\
ABC 0.3\% GO & 88 & 10 & 2 & 0 & 95.2 & 2 & 2.5 & 0.3 \\
ABC 15\% CS & 73 & 10 & 2 & 15 & 95.5 & 2 & 2.5 & 0 \\
ABC 0.3GO-15CS & 73 & 10 & 2 & 15 & 95.2 & 2 & 2.5 & 0.3 \\
\hline
\end{tabular}

\subsection{Setting Properties}

The setting properties of the cement paste were evaluated according to the International Standard ISO 5833-02 [41]. Right after the mixing of the ABC components, the cement was deposited in a $68 \mathrm{~mm}$ diameter and $20 \mathrm{~mm}$ high Teflon mold to record time and temperature data. The plot of the temperature against time allowed calculating the maximum temperature $\left(T_{\max }\right)$, while the setting time $\left(T_{\text {set }}\right)$ was calculated according to Equation (1), as the time for reaching the setting temperature $\left(T_{\text {set }}\right)$.

$$
T_{\text {set }}=\frac{T_{\max }+T_{a m b}}{2}
$$

where $T_{a m b}$ is the ambient temperature, $T_{\max }$ is the highest temperature recorded, the test was carried out at least three times for each formulation.

\subsection{Mechanical Properties}

For the four-point bending test rectangular samples of $75 \mathrm{~mm}$ long, $10 \mathrm{~mm}$ wide, and $3 \mathrm{~mm}$ thick were used. The test was carried out in a universal testing machine (Tinuos Olsen H50KS, Horsham, PA, USA) with a $10 \mathrm{kN}$ load cell, at a rate of $5 \mathrm{~mm} / \mathrm{min}$, according to the ISO 5833-02. The bending strength and bending modulus were calculated using Equations (2) and (3), respectively.

$$
B=\frac{3 F a}{b h^{2}}
$$




$$
E=\frac{\Delta F a}{4 f b h^{3}} \times\left(3 l^{2}-4 a^{2}\right)
$$

where $B$ is the bending strength, $E$ is the bending modulus, $F$ is the force at break, $b$ is the average measured width of specimen, $h$ is the average measured thickness of specimen, $a$ is the distance between the inner and outer loading points, $\Delta F$ is the load range $(50 \mathrm{~N}-15 \mathrm{~N}=35 \mathrm{~N}), f$ is the difference the deflections under the loads of $15 \mathrm{~N}$ and $50 \mathrm{~N}, 1$ is the distance between the outer loading points. At least six specimens were tested for each formulation.

\subsection{In Vitro Studies}

\subsubsection{Antibacterial Activity against Escherichia coli}

Antibacterial activity of ABCs loaded with CS and GO was evaluated against the Gram-negative bacteria E. coli (DH5 $\alpha)$, by colony-forming units (CFU) determined by standardized plate counting agar method reported previously [31]. Briefly, bacterial concentration was estimated at $10^{8} \mathrm{CFU} / \mathrm{mL}$. An aliquot of $100 \mu \mathrm{L}$ of the inoculum test $\left(10^{5} \mathrm{CFU} \cdot \mathrm{cm}^{-2}\right)$ prepared in $1 / 500$ diluted Nuria Broth medium (Sparks, MD, USA, Difco) was placed onto the surface of sterile discs of $10 \mathrm{~mm}$ diameter and incubated for $24 \mathrm{~h}$ at $37^{\circ} \mathrm{C}$. Afterwards, samples were washed with $1 \mathrm{~mL}$ of phosphate buffer solution (PBS) (pH 7.2) and the numbers of $\mathrm{CFU}$ recovered from each sample disc were determined by standardized plate counting agar techniques and referred as $\mathrm{CFU}(\mathrm{N}) / \mathrm{cm}^{2}$. The mean reported for each concentration of filler was based on three replicates. Later, samples of $A B C$ s were observed in a scanning electronic microscopy (SEM) Philips XL30 with tungsten filament (Philips, Eindhoven, The Netherlands).

\subsubsection{Cell Viability}

ABCs cell viability with human osteoblasts cells (HOb) (ECACC 06090739) was carried out by the methylthiazol tetrazolium (MTT) assay as previously reported [31]. Briefly, the corresponding sterilized disc, $10 \mathrm{~mm}$ in diameter and $1.5 \mathrm{~mm}$ of thickness, was submerged in $5 \mathrm{~mL}$ of Dulbecco's modified Eagle's medium-DMEM and incubated at $37^{\circ} \mathrm{C}$ for 1,14 , and 21 days. HOb were seeded in a 96-well plate $\left(9 \times 10^{4}\right.$ cells/well) and exposed to the sample extracts for $24 \mathrm{~h}$; then, a MTT solution $(0.5 \%$ MTT (Sigma, St. Louis, MO, USA) in phosphate buffered saline) was added into the well. After $4 \mathrm{~h}$ of incubation at $37^{\circ} \mathrm{C}$, cell viability was measured using the optical density of the wells at $570 \mathrm{~nm}$ in a microplate reader Synergy HT (Biotek, Winooski, VT, USA). Percentage of cell viability was calculated by Equation (4):

$$
\% \text { Cell viability }=\frac{O D_{s}-O D_{T}}{O D_{C}} \times 100
$$

where $O D_{S}, O D_{T}$, and $O D_{C}$ are the optical density measurements of the sample, the target (MEM medium introduced into wells without cells) and the negative control (Thermanox ${ }^{\circledR}$ ), respectively.

\subsubsection{Cell Adhesion}

$\mathrm{HOb}$ cells were seeded at a density of $9 \times 10^{4}$ cell $/ \mathrm{mL}$ and cultured for $24 \mathrm{~h}$ over the testing specimens placed in a 24-well culture plate. After that, $2 \mathrm{~mL}$ of Alamar Blue dye (10\% Alamar Blue solution in phenol red free DMEM medium) were added to each well. After $4 \mathrm{~h}$ of incubation, specimens were washed twice with PBS in order to remove the rest of the reagent, and $1 \mathrm{~mL}$ of culture medium was added to monitor cell adhesion on the materials. This step was done at 1, 7, 14, and 21 days of incubation and afterwards samples were fixed in an aqueous solution of glutaraldehyde $2.5 \% v / v$. Finally, the ABCs were observed in a scanning electronic microscopy (SEM) Philips XL30 with tungsten filament (Philips, Eindhoven, The Netherlands).

\subsection{In Vivo Studies}

The in vivo studies followed the recommendations of ISO 10993-6 [42] related to the selection and implanted zone requirements for biomodel tests. This research was reviewed, supported, and approved 
by the Institutional Ethics Review Committee with experimental animals of the Universidad del Valle (Cali, Colombia) through act 001 of 2012.

\subsubsection{Subdermal Implantation}

Implantation of samples corresponding to the four ABCs formulations (Table 1) was performed in subdermal tissue of nine male Wistar rats (three months old and $280 \mathrm{~g}$ average weight) to evaluate the in vivo biocompatibility. Porcine collagen membrane samples (Membracel ${ }^{\circledR}$, Buenos Aires, Argentina) were used as a control for biocompatible foreign membranes. The animals were supplied and hosted by the LABBIO laboratory at the Universidad del Valle, Cali, Colombia.

Each experiment consisted of an incision $1 \mathrm{~cm}$ long by $3 \mathrm{~cm}$ deep on the dorsal surface of the rats. The procedure started with sedation by intramuscular application of $70 \mathrm{mg} / \mathrm{kg}$ of ketamine and $30 \mathrm{mg} / \mathrm{kg}$ of xylazine (HOLLIDAY SCOTTS, Buenos Aires, Argentina). After 1 month of implantation, the animals were euthanized by applying pentobarbital sodium $(390 \mathrm{mg} / \mathrm{mL})$ and diphenylhydantoin sodium $(50 \mathrm{mg} / \mathrm{mL})\left(\right.$ Euthanex $^{\circledR}$, laboratory INVENT, Colombia) in a dose of $100 \mathrm{mg} / \mathrm{kg}$ with intraperitoneal application.

The recovered samples were fixed for $48 \mathrm{~h}$ in buffered formalin; then, the soft tissue capsule surrounding the implanted material was opened to remove the bone cement samples and analyze the morphology by SEM (JEOL Model JSM 6490 LV, Akishima, Tokyo, Japan).

Soft tissue samples were processed using a Leica TP1020 automatic tissue processor (Leica Biosystems, Buffalo Grove, IL, USA), in alcohol solutions with ascending concentration (70, 80, 95 and $100 \%$ ) and xilol. Right after, the processed tissue samples were embedded in paraffin blocks using a Shandon Histocentre ${ }^{\mathrm{TM}}$ REF8330 embedding center (Thermo Fisher Scientific ${ }^{\mathrm{TM}}$, Waltham, MA, USA) and cut into $5 \mu \mathrm{m}$ sheets using a microtome (Leica Biosystems RM2245, Buffalo Grove, IL, USA). The cut tissue samples were stained with Hematoxylin-Eosin and Masson's Trichrome techniques. For the analysis of histological images, a Leica DM 750 microscope coupled to a Leica DFC camera was used, and the data were processed using the Leica Suite software version 4.12.0 (Leica Microsystems, Wetzlar, Germany).

\subsubsection{Bone Implantation Study}

Following the same sedation protocol of the subdermal implantation, a defect of $5 \mathrm{~mm}$ in diameter was made in the parietal bone of 15 Wistar rats of 8 months old and $370 \mathrm{~g}$ average weight. The generated defect was filled with the corresponding $\mathrm{ABC}$ formulation and the defect sutured as observed in the photography of the parietal bone animal zones (Figure S1).

After 3 months of implantation, animals were euthanized following the same procedure described in the subdermal implantation. Tissues of $1 \times 1 \mathrm{~cm}^{2}$ containing the implanted $A B C$ and original peripheral bone were recovered. Samples were fixed in $10 \%$ buffered formalin for $48 \mathrm{~h}$, washed with distilled water and dehydrated by passing through increasing ethanol solutions of 30, 50, 70 and 90\% for $10 \mathrm{~min}$ and in pure ethanol for $1 \mathrm{~h}$. Finally, the samples were stored for at least $48 \mathrm{~h}$ in a desiccator at room temperature and analyzed by SEM and x-ray energy dispersive spectrometry (EDS) techniques (JEOL Model JSM 6490 LV, Akishima, Tokyo, Japan). In this analysis, areas of interest at the cement, interface, and bone zones were analyzed for each sample composition as illustrated in the supporting information section.

\subsection{Statistical Analysis}

Values of setting and mechanical properties, cell viability, and antibacterial activity were presented as mean \pm SD. Statistical analyses was performed using Student's $t$-test. Statistical analysis was performed comparing modified $\mathrm{ABC}$ s samples with respect to Control ABC. Differences were considered statistically significant at ${ }^{*} p<0.05$ and ${ }^{* *} p<0.01$. 


\section{Results and Discussion}

\subsection{Setting Properties}

Table 2 demonstrates that CS and GO separately added to the cement decreased the maximum temperature $\left(T_{\max }\right)$ during polymerization and increased the setting time $\left(T_{\text {set }}\right)$. However, the formulation containing both components presented a synergy in reducing $T_{\text {max }}$ and increasing $T_{\text {set }}$ by more than $21 \%$. All the values of setting parameters in Table 2 are within the limits allowed by ISO 5833-02 [41], which sets a maximum temperature limit of $90^{\circ} \mathrm{C}$ and a curing time between 3 and $15 \mathrm{~min}$.

Table 2. Maximum temperature $\left(T_{\max }\right)$ and setting time $\left(T_{\text {set }}\right)$ values recorded for ABCs formulations. Data are reported as a mean $\pm \mathrm{SD}$.

\begin{tabular}{ccc}
\hline Formulation & $\boldsymbol{T}_{\max }\left({ }^{\circ} \mathrm{C}\right)$ & $\boldsymbol{T}_{\text {set }}$ (min) \\
\hline Control ABC & $59 \pm 3$ & $355 \pm 30$ \\
ABC 0.3\% GO & $51 \pm 4$ & $420 \pm 25$ \\
ABC 15\% CS & $55 \pm 4$ & $460 \pm 20 *$ \\
ABC 0.3GO-15CS & $46 \pm 3 *$ & $440 \pm 10^{*}$ \\
\hline
\end{tabular}

Asterisks denote significant differences of modified $A B C$ samples with respect to Control ABC at a significance level of ${ }^{*} p<0.05$.

Reduction of $T_{\max }$ is particularly important to assure the patient's healthiness, reducing the risk of tissue necrosis. Some reported cements had $T_{\max }$ up to $100{ }^{\circ} \mathrm{C}$ demonstrating a high patient risk [43].

According to Paz et al. [44], the decrease in polymerization heat observed in GO formulations, suggests that it retards and inhibits the curing reaction by interfering with the radical reaction. This was also confirmed by Ormsby et al. [45] who proposed that the chemical interaction between PMMA and carboxyl functionalized multi-walled carbon nanotubes (MWCNT-COOH) occurs through two mechanisms: A covalent bonding of the MWCNTs with the growing polymer chains via esterification reactions, or GO nanosheets acting as heat dissipaters.

On the other hand, Gonçalves et al. [46] proposed that GO acts as a radical scavenger that inhibits or delays the free radical polymerization reaction, which is consistent with the increase in setting time and the $T_{\max }$ reduction. CS addition in ABCs has also been observed as the main factor for decreasing $T_{\text {max }}$ through a heat dissipation mechanism [9].

\subsection{Mechanical Properties}

According to standard ISO 5833-02 [41] compressive and bending properties of ABC are crucial for good biomechanical performance of $\mathrm{ABC}$. In a previous paper results of compression test of developed ABCs were already reported [31]. Table 3 presents results of the bending test reported in this paper. Compression and bending strengths and bending modulus were significantly reduced $(p<0.01)$ with the incorporation of $15 \%$ CS compared to Control ABC; even when $15 \%$ CS was added together with $0.3 \%$ GO compressive strength significantly decreased although it still remained higher than $70 \mathrm{MPa}$ that is the minimum value allowed by the standard. However, for the $\mathrm{ABC}$ that contained both CS and GO bending strength was not significantly different with respect to Control ABC. On the other hand, the introduction of GO to ABCs by its own did not showed significant differences of the mechanical properties with respect to Control ABC.

Some researchers have reported improvements in tensile, compressive [7] and flexural properties [13] in bone cements with GO incorporation. The improvement is caused by a stronger interfacial interaction between GO and PMMA generated by a high amount of hydroxyl and carboxyl groups present on the GO surface [44].

On the other hand, some studies reported negative effects in the mechanical properties with CS introduction $[47,48]$. The interference of the polysaccharide in the polymerization of MMA and the irregular morphologies of this component that acts as an accumulator of stress are the main reasons for the detrimental effect [31]. Despite that, evidence of the reinforcing effect of GO functionalization 
with CS has been reported [49-51] arguing chemical reactions between the amino groups of CS and the carboxyl groups of the GO, what indicates that the presence of both fillers is crucial for the properties improvement.

Table 3. Compressive strength (C), bending strength (B) and bending modulus (E) in ABCs formulations. Data are reported as a mean $\pm \mathrm{SD}$.

\begin{tabular}{cccc}
\hline Formulation & C (MPa) [31] & B (MPa) & E (MPa) \\
\hline Control ABC & $93.3 \pm 2.2$ & $48.7 \pm 4.2$ & $2593 \pm 178$ \\
ABC 0.3\% GO & $94.0 \pm 0.5$ & $51.8 \pm 0.4$ & $2599 \pm 154$ \\
ABC 15\% CS & $62.6 \pm 1.1^{* *}$ & $32.8 \pm 2.9 * *$ & $2141 \pm 212 * *$ \\
ABC 0.3GO-15CS & $77.2 \pm 2.6^{* *}$ & $44.6 \pm 4.1$ & $2379 \pm 132 *$ \\
\hline
\end{tabular}

Asterisks denote significant differences of modified ABC samples with respect to Control ABC at significance levels of ${ }^{*} p<0.05 ; * * 0.01$.

\subsection{In Vitro Studies}

\subsubsection{Antibacterial Activity against Escherichia coli}

E. coli has been used in this research only as a model to evaluate the antimicrobial activity of different modifications of bone cements and prove that the biological activity of the GO and CS is maintaining after curing reaction of $\mathrm{ABC}$. Previous results [31] shows that the CFU of E. coli for Control $\mathrm{ABC}, \mathrm{ABC} 0.3 \% \mathrm{GO}, \mathrm{ABC} 15 \% \mathrm{CS}$ and $\mathrm{ABC} 0.3 \mathrm{GO}-15 \mathrm{CS}$ were $96 \pm 3,17 \pm 2,69 \pm 2$ and $12 \pm 6$, respectively. The former indicate than the effect of $\mathrm{GO}$ incorporation on the antibacterial activity of ABCs was much more significant compared to the introduction of only CS. ABCs loaded with GO showed a reduction in CFU by more than $80 \%$, while those containing only CS reduced the number of colonies by $28 \%$, as compared to the Control $\mathrm{ABC}$. The result obtained for $\mathrm{ABC}$ s with both loadings (CS and GO) did not show statistical significance comparative with ABC loaded with $0.3 \%$ of GO.

SEM micrographs of cements with bacteria (Figure 1) confirmed a higher bacterial population with the formulations that did not contain GO. These results suggested that GO introduction is the main caused for antibacterial activity of $\mathrm{ABCs}$ and is promising for clinical applications devoted to avoiding bacterial infections, a common health risk during surgeries and implantations.
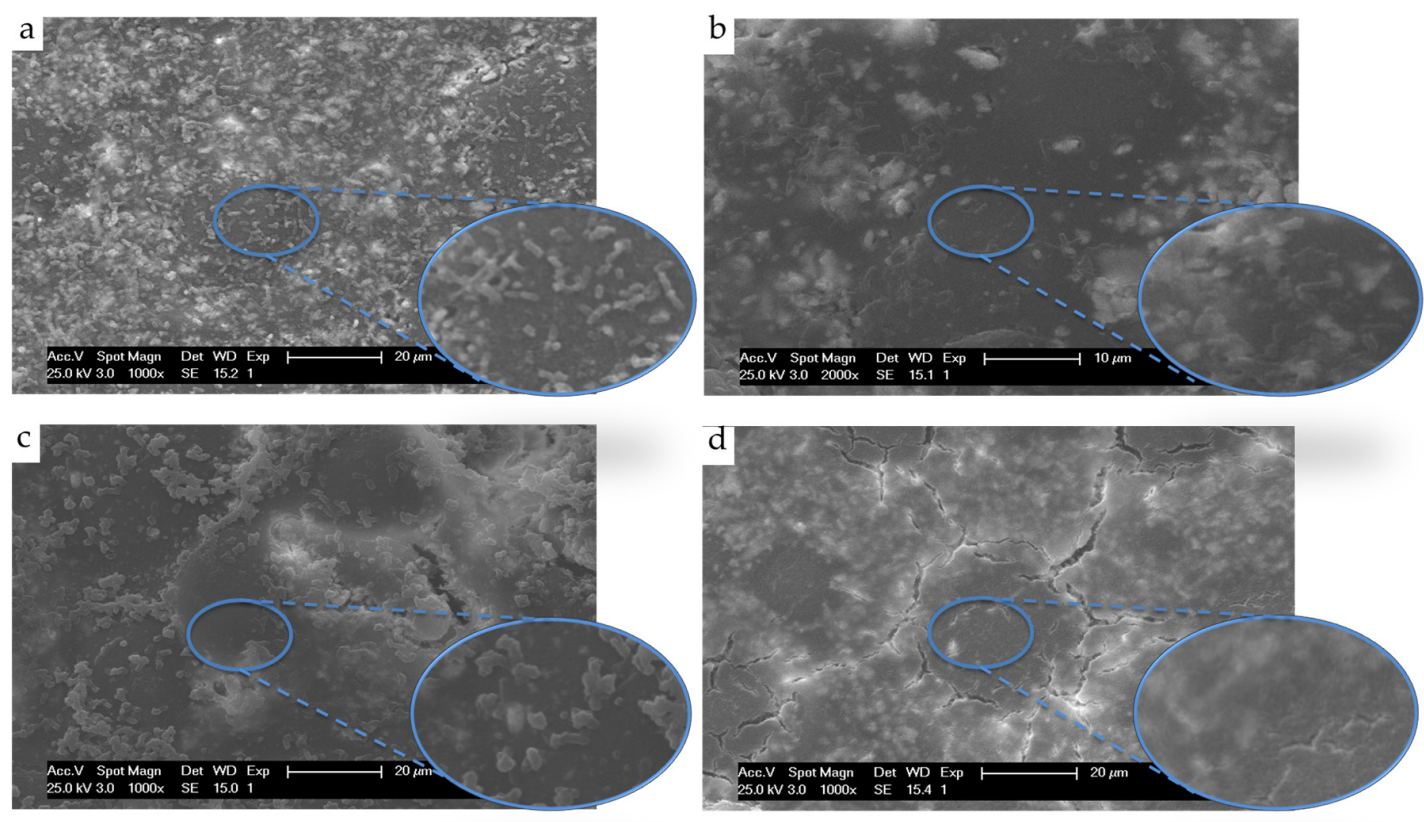

Figure 1. SEM micrographs (1000×) of $A B C$ surfaces after incubation of E. coli cultures for 24 h of (a) Control ABC, (b) ABC with $0.3 \% \mathrm{GO}$, (c) ABC with $15 \% \mathrm{CS}$ and (d) ABC with $0.3 \% \mathrm{GO}$ and $15 \% \mathrm{CS}$. 
Mori et al. [9] reported low antibacterial activity of CS in ABC formulations, suggesting the need to add other synergistic antibacterial properties. The mechanisms of the antimicrobial activity of CS involve electrostatic interactions between the positively charged chitosan chains and bacterial cell membrane, affecting cell permeability and leading to bacterial death [12]. Membrane damage, interaction with DNA/RNA, metal chelation and deposition on the microbial surface are also other possible chitosan antimicrobial mechanisms reported [52]. In this work, the antibacterial activity exhibited by the studied $\mathrm{ABC}$ s is enhanced by the presence of GO which presents antibacterial mechanisms due to its extremely sharp edges that cause physical damage to the bacterial membrane [49,50]. In addition, oxidative stress with production of reactive oxygen species (ROS) disrupts the balance in redox processes within the cell leading to a disruptive membrane cell mechanism [53-57] and cell lysis [53,58].

\subsubsection{Cellular Behavior of Human Osteoblasts}

SEM micrographs of Figure 2 show the surface morphology of the different cement samples directly seeded with human osteoblasts and cultured for 1, 7, 14, and 21 days. It is evident that cement surfaces containing CS showed a rough topography (Figure $2 \mathrm{i}-\mathrm{o}$ ). This topography can be caused by the high viscosity of the CS containing cement paste, which increases the porosity in the matrices [31]. At day 1, a rapid adhesion of HObs (marked with red triangles in Figure 3) with homogeneous distribution was evident across the surface of all cement formulations. After 14 days, individual cells were no longer visible; instead, it was possible to observe a continuous monolayer of extracellular matrix and cells covering all the studied samples. Remarkably, a deeper analysis of the ABC0.3GO-15CS images showed rougher surfaces for this composition revealing a qualitatively superior population of osteoblasts along with higher extracellular matrix formation. Only if cells are alive and functional healthy tissues are synthesized [59] what supports the good biocompatibility of the $A B C$ s prepared in this study.
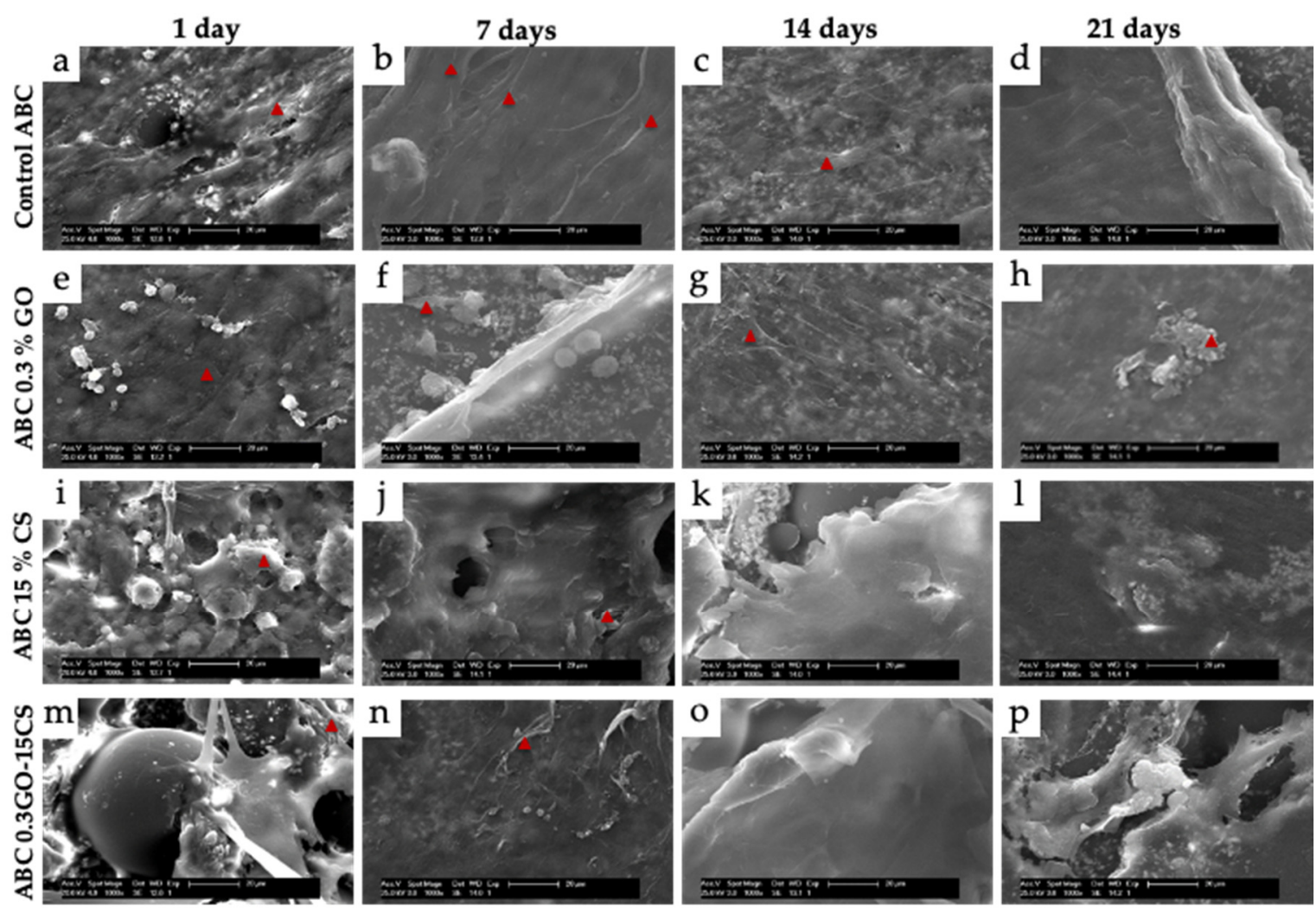

Figure 2. SEM micrographs of $A B C$ samples seeded with human osteoblasts after 1, 7, 14, and 21 days of culture (triangles indicate osteoblasts). (a-d) Control ABC, (e-h) ABC 0.3\% GO, (i-1) ABC $15 \%$ CS and (m-p) ABC 0.3GO-15CS. 

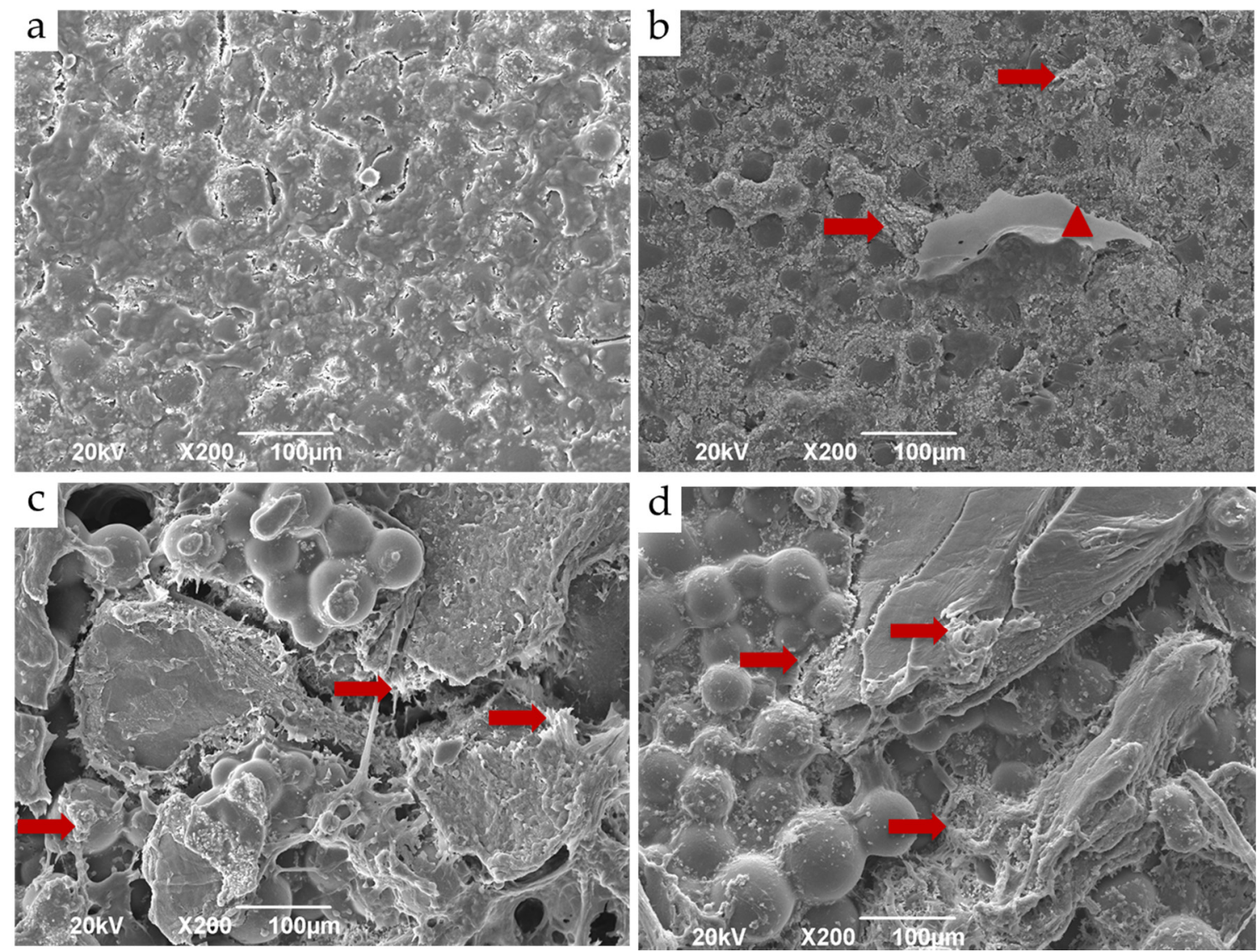

Figure 3. SEM micrographics (200×) of ABC surfaces after subdermal implantation in rats for 1 month.

(a) Control ABC, (b) ABC with $0.3 \%$ GO, (c) ABC with $15 \% \mathrm{CS}$ and (d) ABC with $0.3 \% \mathrm{GO}$ and $15 \% \mathrm{CS}$ samples (Triangles indicate cells and arrows indicate extracellular matrix).

The positive effects of GO and CS on the osteoblasts adhesion, proliferation and deposition of extracellular matrix have been reported by several authors $[7,27,60]$ and they were attributed, in the case of GO introduction, to the increase in the hydrophilicity of the cement surface with hydroxyl groups, which can act as possible anchoring points for cells [7]. In the case of CS, they are related to the low toxicity and excellent ability to promote osteoblastic cell growth of this polysaccharide [27].

\subsection{In Vivo Studies}

In vivo biocompatibility of the developed $\mathrm{ABC}$ s was carried out by application of two different animal models. In particular, these studies consisted of subdermal and bone implantations. Subdermal ABCs implantation was analyzed by SEM and histology of tissues with Hematoxylin and Eosin stain and Masson-trichrome stains. For its part, implantations in parietal bones were evaluated by SEM and EDS studies at the implantation zone.

\subsubsection{Subdermal Implantation}

The SEM micrographs shown in Figure 3 correspond to representative images of the four cements response after 1 month of subdermal implantation in Wistar rat tissues. In Figure 3b, a structure compatible with one cell (marked with triangle in Figure 3) is observed, while Figure 3c,d showed better surface texture and abundant deposits of extracellular matrix on their surface (marked with arrows in Figure 3), compared with the Control ABC (Figure 3a). Since cells of mesenchymal origin, including fibroblasts, are rugophilic, it is valid to think that the surface of the loaded cements, being more irregular than the Control $\mathrm{ABC}$, is more encouraging for the cells. Several pieces of research had demonstrated that a higher roughness of the surface of the biomaterials favors the adhesion and 
proliferation of the cells [61-65]. The presence of cells and deposits of extracellular matrix on the cements confirmed their biocompatibility because according to Richards [61], the adhesion of cells to surfaces is one of the vital aspects in biocompatibility.

As far as histological analysis, the samples corresponding to the collagen control at 1 month of implantation are showed in Figure 4 which revealed the presence of remaining material $(\mathrm{Col})$ in the implantation zone (IZ) in process of degradation/absorption and abundant inflammatory infiltration (II).

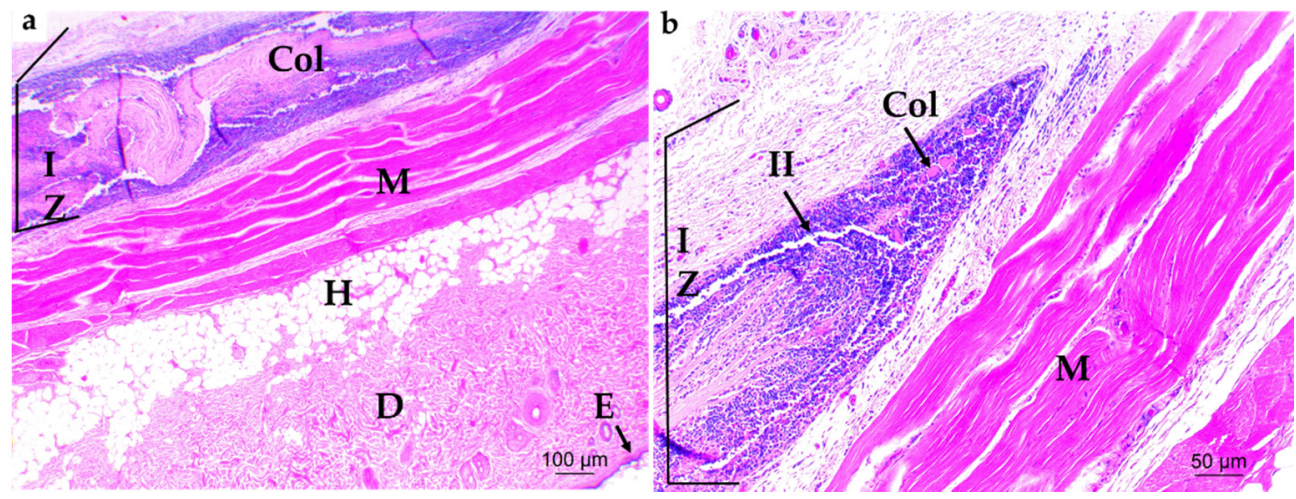

Figure 4. H\&E staining of collagen membrane after 1 month of subdermal implantation in Wistar rats. (a) $4 \times$ and (b) 10×. IZ: Implantation zone. Col: Collagen. M: Muscle. H: Hypodermis. D: Dermis. E: Epidermis. II: Inflammatory infiltrate.

Figure 5 corresponds to the Control $\mathrm{ABC}$ formulation, showing a capsule (C) surrounding the zone of implantation (IZ) and including an inflammatory infiltrate (II).

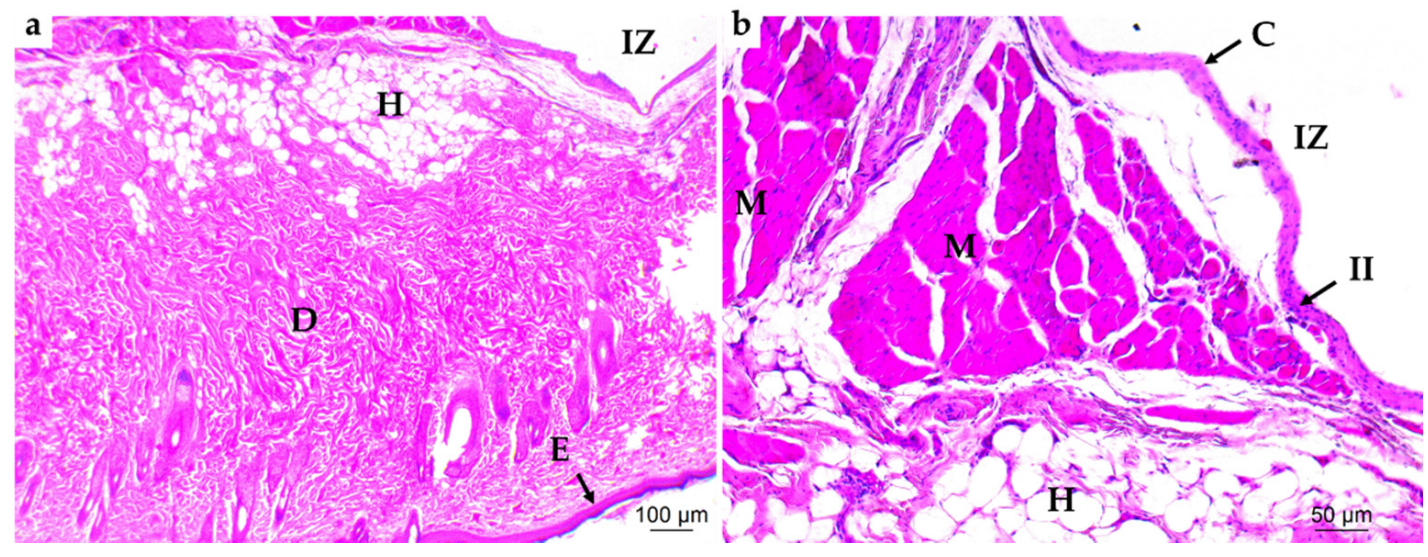

Figure 5. H\&E staining of Control $A B C$ after 1 month of subdermal implantation in Wistar rats.

(a) $4 \times$ and (b) 10×. IZ: Implantation zone. Col: Collagen. M: Muscle. H: Hypodermis. D: Dermis.

E: Epidermis. II: Inflammatory infiltrate and C: capsule.

The three formulations of implanted cements including GO and/or CS (Figure 6) showed similar response to that of Control ABC (Figure 5), characterized by a localized inflammatory response, surrounded by a capsule (C) with the presence of inflammatory infiltrate (II). However, compared to collagen samples (Figure 4), the latter had a more diffuse inflammatory response with abundant inflammatory infiltrate.

The tissues stained with the Masson's trichrome stain (Figure 7) showed a fibrous capsule at the IZ composed of collagen type I fibers for collagen control and the studied cements. 

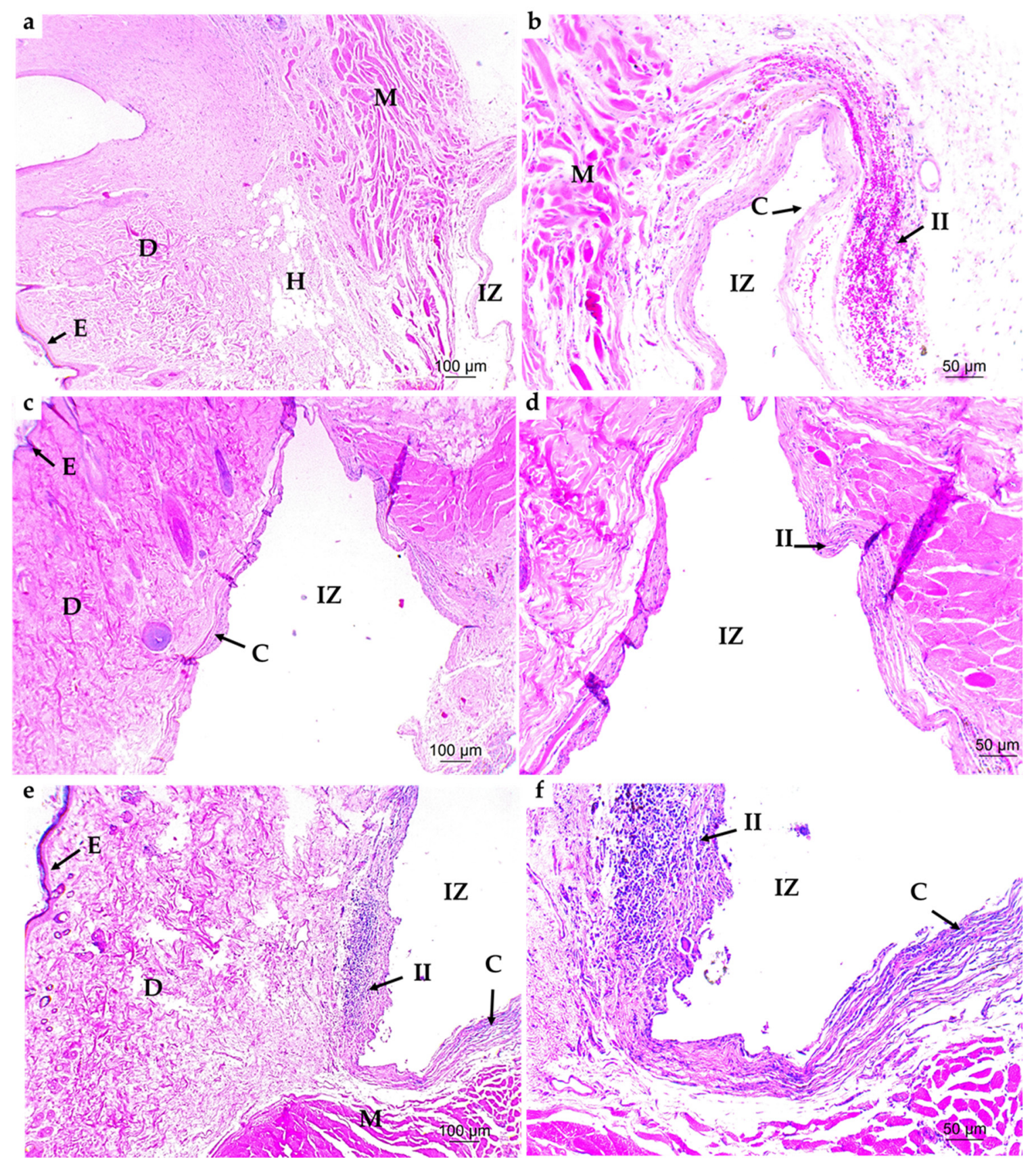

Figure 6. H\&E staining after 1 month of subdermal implantation in Wistar rats. (a,b) ABC with $0.3 \%$ GO, (c,d) ABC with $15 \%$ CS and (e,f), ABC with $0.3 \%$ GO and $15 \%$ CS. (a-c,e) micrographs to $4 \times$ and $4 \times$, and $(\mathbf{b}-\mathbf{d}, \mathbf{f})$, micrographs at 10×. IZ: Implantation zone. M: Muscle. H: Hypodermis. D: Dermis. E: Epidermis. II: Inflammatory infiltrate and C: capsule.

The presence of the capsule and the inflammatory infiltrate surrounding the cement samples can be considered a normal in vivo response to materials that have been implanted in soft tissue and promote healthy wound healing [66]. For example, Maiborodin et al. [67] reported the formation of a transparent capsule surrounding samples of polyhydroxyalkanoates implanted in rats. Fibrous encapsulation has also been reported for various biomaterials, such as nano-crystalline hydroxyapatite [68] and ABCs with CS [4]. 


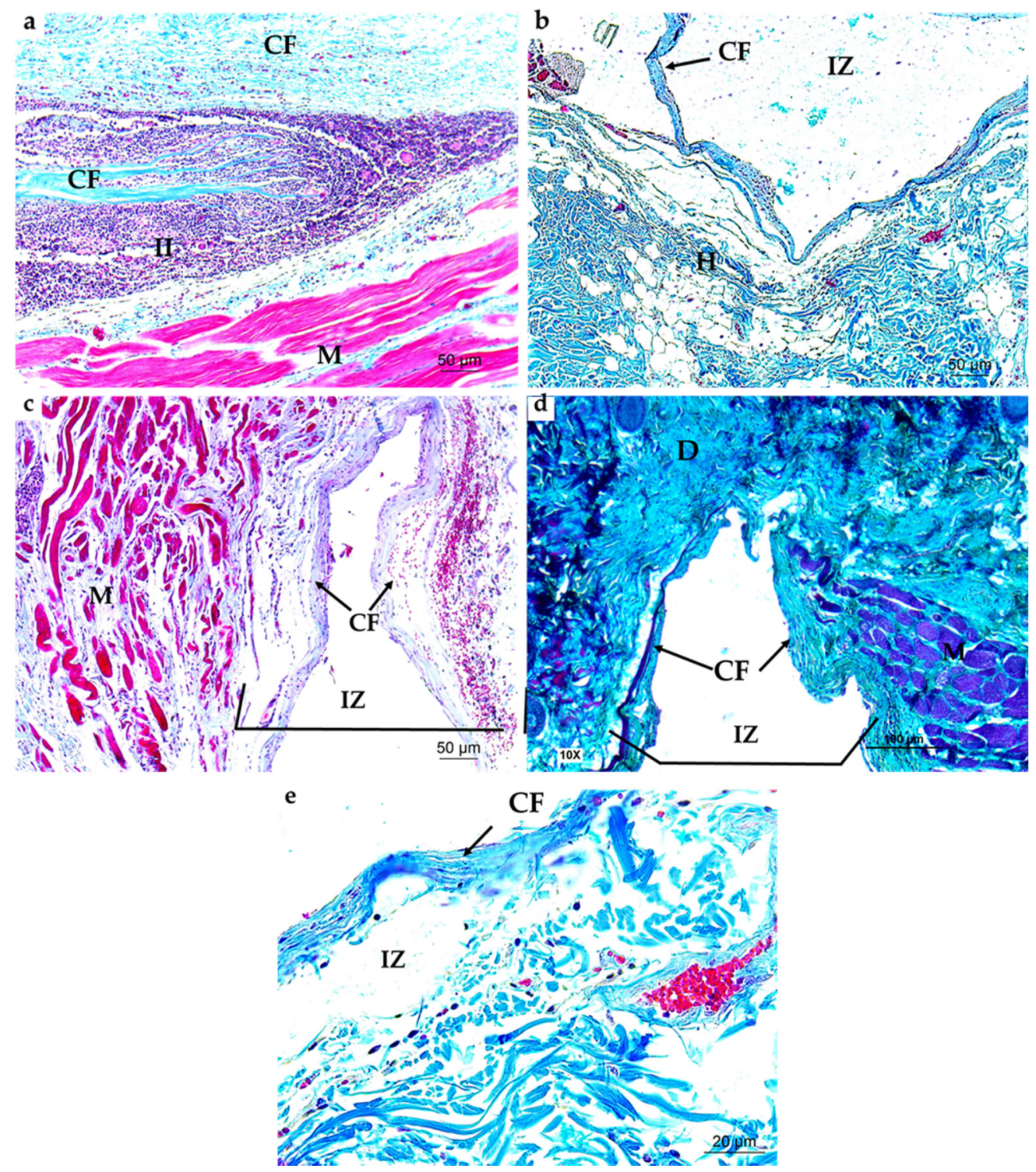

Figure 7. Micrographics of Masson's trichrome stain after 1 month of subdermal implantation in Wistar rats (10×). (a) Collagen control, (b) Control ABC, (c) ABC with 0.3\% GO, (d) ABC with 15\% CS and (e) ABC with $0.3 \%$ GO and 15\% CS. IZ: Implantation zone. M: Muscle. H: Hypodermis. II: Inflammatory infiltrate. CF: Collagen fibers.

\subsubsection{Bone Implantation of $\mathrm{ABCs}$}

SEM and EDS studies were performed at the interface of bone and cements to evaluate the osseointegration process through the sealing defect and to detect the presence of $\mathrm{Ca}$ and $\mathrm{P}$, respectively.

According to the SEM micrographs illustrated in Figure 8, Control ABC implantation area in parietal bone of Wistar rats showed that after 3 months of implantation, the cement was not completely integrated with the surrounding bone tissue, since a clear separation between the two was observed (Figure $8 \mathrm{a}, \mathrm{b}$ ). In the area corresponding to the cement, the typical topography of the bone cement was observed with few deposits of extracellular matrix (EM).

On the contrary, the formulations modified with GO (Figure 9a,b) or CS (Figure 9c,d) and with both components together (Figure 9e,f) presented the bone-cement interface with an advanced sealing process. In addition, at the interface there were presence of osteoblasts $(\mathrm{OB})$ and abundant deposits of EM that nearly completely seal the periphery of the intraosseous preparation as shown in Figure 9. The better sealing means an enhanced osseointegration or chemical affinity of the modified ABCs 
with the bone. In accordance, the difference in the EM deposits between the Control ABC and the modified cements (Figures 8 and 9 respectively) is evident. Interestingly, cement with both CS and GO presented a more active interface with a group of osteoblasts growing from the interface towards the bone cement (Figure 9e,f).

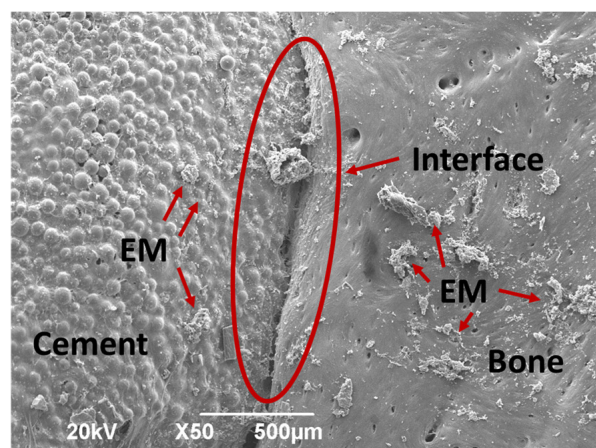

(a)

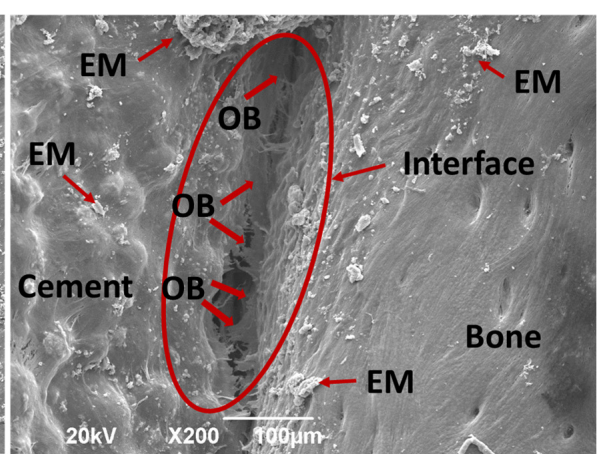

(b)

Figure 8. Micrographs of the implantation zone of Control ABC after 3 months of implantation in parietal bone of Wistar rats. (a) 50× and (b) 200×. EM: Extracellular matrix and OB: Osteoblasts.
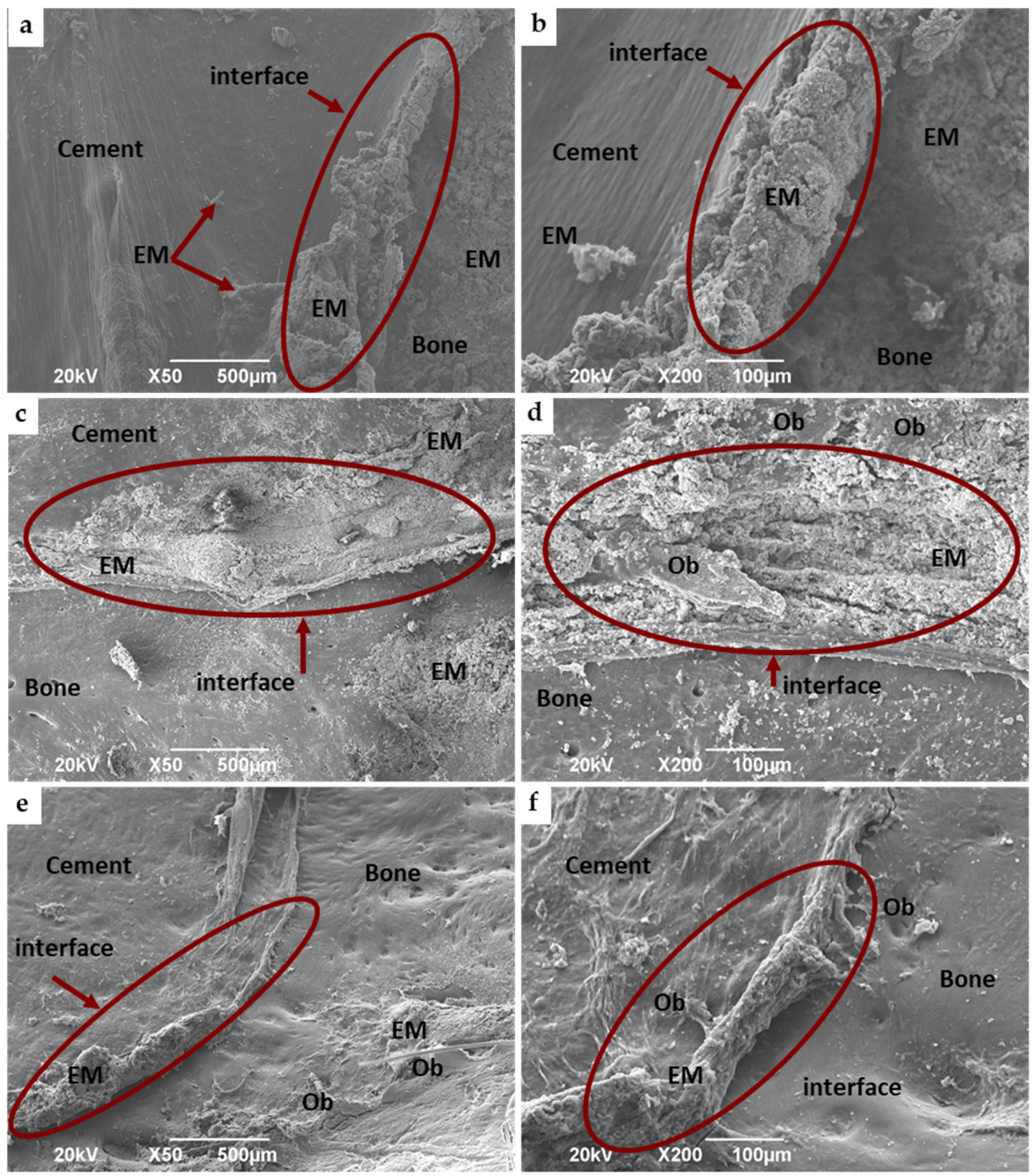

Figure 9. SEM micrographs of the implantation zone of modified ABCs after 3 months of implantation in parietal bone of Wistar rats. (a,b) ABCs with $0.3 \% \mathrm{GO},(\mathbf{c}, \mathbf{d}) \mathrm{ABC}$ with $15 \% \mathrm{CS}$ and, (e,f) ABCs with $0.3 \%$ GO and $15 \%$ CS. $(\mathbf{a}, \mathbf{c}, \mathbf{e})$ with $50 \times$ magnification. Areas surrounded by a red line are showed with deeper detail $(200 \times)$ in $(\mathbf{b}, \mathbf{d}, \mathbf{f})$ images, respectively. EM: Extracellular matrix and OB: Osteoblasts. 
When the cement-bone interface of the ABC 15\% CS and ABC0.3\% GO-15\% CS formulations were analyzed at higher magnification (500×) (Figure 10) it was appreciated that the interface of ABCs modified with only CS was not totally sealed, showing cement particles in the process of cellular colonization, while that of the ABC $0.3 \%$ GO-15\% CS formulation was almost completely sealed.
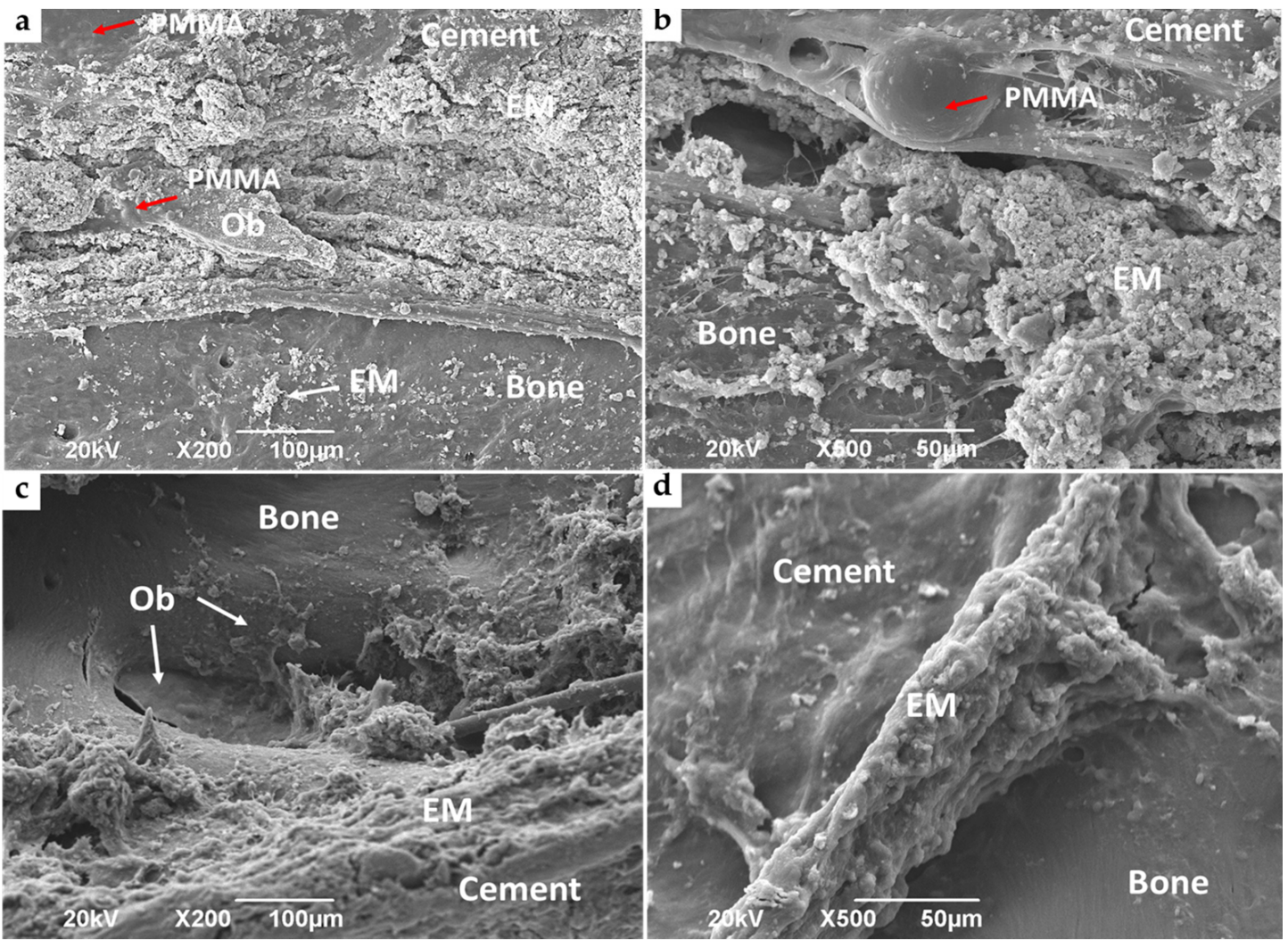

Figure 10. SEM micrographs of the implantation zone of modified ABCs after 3 months of implantation in parietal bone of Wistar rats. (a,b) ABC 15\% CS, (c,d) ABC with $0.3 \%$ GO and $15 \%$ CS. (a,c) $200 \times$ and (b,d) 500×. EM: Extracellular matrix, OB: Osteoblasts and PMMA: bead of PMMA.

Analysis of EDS spectra at the interface and the bone zones (Figure 11) in all cases demonstrated the presence of bands of calcium $(\mathrm{Ca})$ and phosphorous $(\mathrm{P})$ in their corresponding spectra (Figure $11 \mathrm{~b}, \mathrm{c}, \mathrm{e}, \mathrm{f}, \mathrm{h}, \mathrm{i}, \mathrm{k}, \mathrm{l})$ supporting the mineralization process and the good biocompatibility of the ABCs studied here. However, analysis of EDS spectra in the cement IZ showed the presence of the Ca signal of low intensity and absence of the that of P (Figure 11a,d,g,j).

Interestingly, increasing amounts of $\mathrm{Ca}$ and $\mathrm{P}$ were found for the formulations with $0.3 \% \mathrm{GO}$ and/or 15\% CS with respect to Control ABC, more marked for the sample containing both components (Figure S2). The deposition of $\mathrm{Ca}$ and $\mathrm{P}$ elements is a primary evidence of the osteogenesis process and the amount of elemental deposition is associated with a material biocompatibility and osteoconductive behavior [43].

These results agree with those previously obtained by SEM, since the enhanced biomineralization at the interface for the $\mathrm{ABC}$ with $0.3 \% \mathrm{GO}$ and $15 \% \mathrm{CS}$ sample correlates with a greater integration of this cement with the bone and with an improved biocompatibility compared to the other studied formulations. The foregoing indicates that this formulation is highly promising stimulating bone regeneration and therefore it has potential for the fixation of orthopedic implants to the bone, mainly in applications where osseointegration is required. 

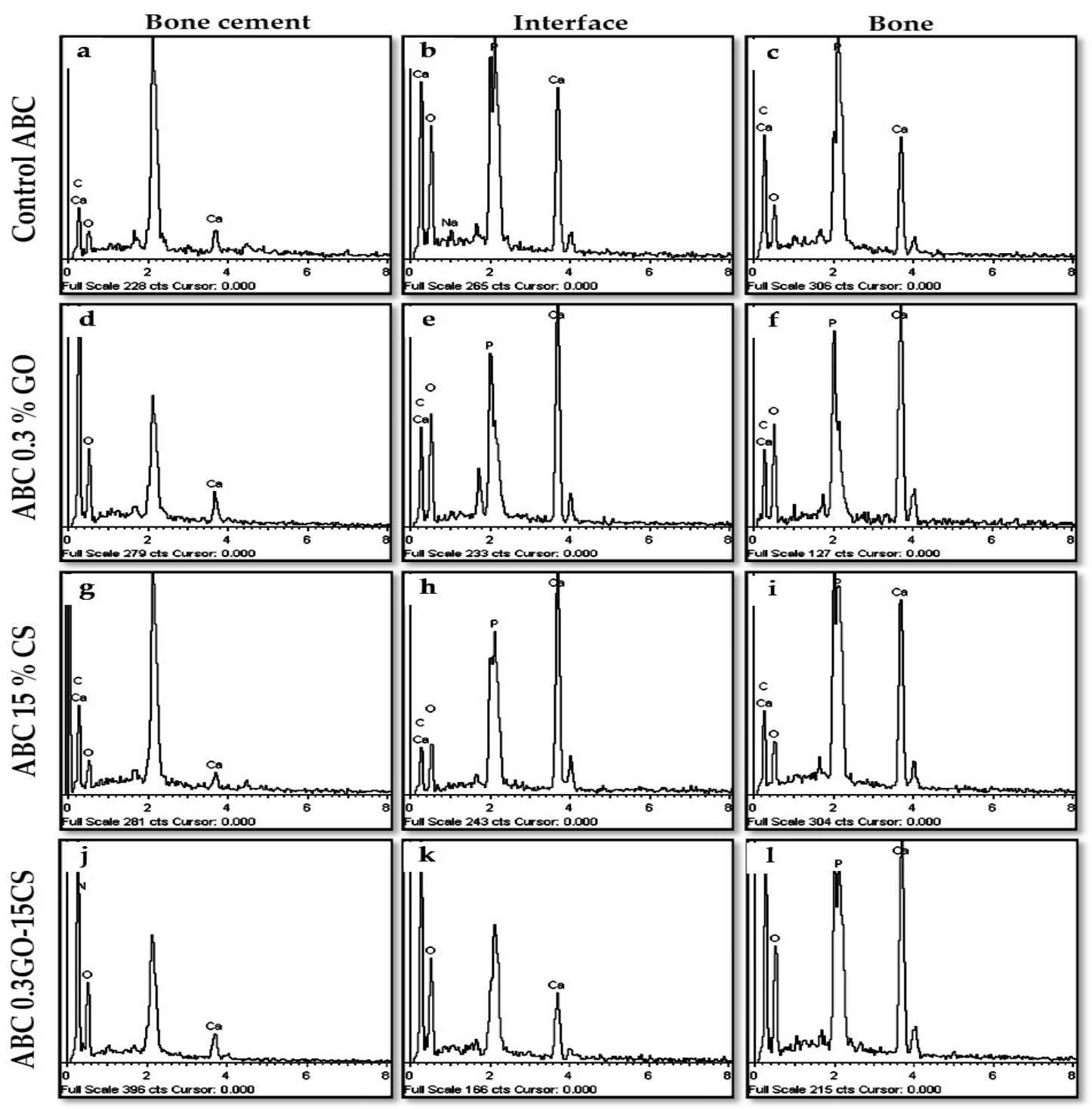

Figure 11. EDS analysis of the implantation zone of ABCs after 3 months of implantation in critically sized bone defects in the parietal bone of Wistar rats. $(\mathbf{a}, \mathbf{d}, \mathbf{g}, \mathbf{j})$ correspond to the ABC zone; $(\mathbf{b}, \mathbf{e}, \mathbf{h}, \mathbf{k})$ correspond to the interface and $(\mathbf{c}, \mathbf{f}, \mathbf{i}, \mathbf{l})$ correspond to the bone around the cement. $(\mathbf{a}-\mathbf{c})$ Control ABC, $(\mathbf{d}-\mathbf{f}) \mathrm{ABC}$ with $0.3 \%$ GO, (g-i) ABC with 15\% CS and (j-1) ABC with $0.3 \%$ GO and $15 \%$ CS samples.

\section{Conclusions}

Inclusion of CS and GO separately or together in cement formulations improved setting properties and biocompatibility both in vitro and in vivo, although incorporation of only CS showed a decrease in the mechanical properties of ABCs. The synergy of the contribution of GO and CS was evident in the $\mathrm{ABC} 0.3 \% \mathrm{GO}-15 \% \mathrm{CS}$ formulation providing a significant decrease in the maximum temperature and an increase in the antibacterial activity compared to the other formulations. All formulations showed biocompatibility against human osteoblasts and in a subdermal model in rats.

Implantation of modified cements in parietal bone of rats showed that all the ABCs favored healthy sealing of the critical size defect. However, an improved process of osseointegration and biocompatibility were observed in the cements modified with $0.3 \%$ GO and $15 \%$ CS, since they show a more mature interface with a group of osteoblasts colonizing the surface of the bone cement, abundant deposits of EM and notable presence of $\mathrm{Ca}$ and $\mathrm{P}$ elements at the interface. These late corroborates the positive synergistic effect between GO and CS in the bioactivity of the ABCs and its promising use as a bioactive $\mathrm{ABC}$ for the fixation of orthopedic implants to the bone. 
Supplementary Materials: The following are available online at http://www.mdpi.com/2076-3417/10/18/6528/s1, Figure S1: Sequence of implantation of ABCs in parietal bone of Wistar rats. Figure S2: MTT assay performed with $\mathrm{HOb}$ in the presence of extracts of ABCs taken after 1, 14, and 21 days. Figure S3: EDS analysis of the implantation zone of ABCs after 3 months of implantation in critically sized bone defects in the parietal bone of Wistar rats.

Author Contributions: Conceptualization, M.E.V.Z., J.H.M.H. and C.D.G.T.; methodology, M.E.V.Z., J.H.M.H., C.D.G.T., C.H.V.L., B.V.-L., J.S.R. and L.R.; investigation, M.E.V.Z., J.H.M.H. and C.D.G.T.; writing-original draft preparation, M.E.V.Z.; writing-review and editing, M.E.V.Z., C.H.V.L., C.D.G.T., B.V.-L. and L.R.; funding acquisition, J.H.M.H. and J.S.R. All authors have read and agreed to the published version of the manuscript.

Funding: This research was funded by Sistema General de Regalías funded this research-FCTeI-Colombia (BPIN: 2013000100300), Spanish AEI/FEDER/UE MAT2015-73656-JIN and MAT2017-84277-R, and Health Institute Carlos III (CIBER-BBN).

Acknowledgments: The authors acknowledge Rosa Ana Ramirez Jimenez of the Biomaterials Group of the Instituto de Ciencia y Tecnología de Polímeros, ICTP-CSIC, Spain for the support in the in vitro assays. The authors acknowledge to the Sistema General de Regalías-FCTeI-Colombia (BPIN: 2013000100300) for funding the research. Author Mayra Eliana Valencia Zapata acknowledges to MinCiencias for funding her doctoral studies. The authors Blanca Vázquez-Lasa and Luis Rojo are members of the SusPlast platform from the Spanish National Research Council (CSIC).

Conflicts of Interest: The authors declare no conflict of interest.

\section{References}

1. Slane, J.; Vivanco, J.; Meyer, J.; Ploeg, H.L.; Squire, M. Modification of acrylic bone cement with mesoporous silica nanoparticles: Effects on mechanical, fatigue and absorption properties. J. Mech. Behav. Biomed. Mater. 2014, 29, 451-461. [CrossRef] [PubMed]

2. Lissarrague, M.H.; Fascio, M.L.; Goyanes, S.; D'Accorso, N.B. Acrylic Bone Cements: The Role of Nanotechnology in Mechanical Properties. J. Biomed. Nanotechnol. 2014, 10, 3536-3557. [CrossRef] [PubMed]

3. Franco-Marquès, E.; Méndez, J.A.; Gironès, J.; Ginebra, M.P.; Pèlach, M.A. Evaluation of the influence of the addition of biodegradable polymer matrices in the formulation of self-curing polymer systems for biomedical purposes. Acta Biomater. 2009, 5, 2953-2962. [CrossRef] [PubMed]

4. Endogan, T.; Kiziltay, A.; Kose, G.T.; Comunoglu, N.; Beyzadeoglu, T.; Hasirci, N. Acrylic bone cements: Effects of the poly(methyl methacrylate) powder size and chitosan addition on their properties. J. Appl. Polym. Sci. 2014, 131, 39662. [CrossRef]

5. Webb, J.C.J.; Spencer, R.F. The role of polymethylmethacrylate bone cement in modern orthopaedic surgery. J. Bone Jt. Surg. 2007, 89, 851-857. [CrossRef]

6. Yan, F.; Liu, Z.; Zhang, T.; Zhang, Q.; Chen, Y.; Xie, Y.; Lei, J.; Cai, L. Biphasic Injectable Bone Cement with $\mathrm{Fe}_{3} \mathrm{O}_{4} / \mathrm{GO}$ Nanocomposites for the Minimally Invasive Treatment of Tumor-Induced Bone Destruction. ACS Biomater. Sci. Eng. 2019, 5, 5833-5843. [CrossRef]

7. Pahlevanzadeh, F.; Bakhsheshi-Rad, H.R.; Hamzah, E. In-vitro biocompatibility, bioactivity, and mechanical strength of PMMA-PCL polymer containing fluorapatite and graphene oxide bone cements. J. Mech. Behav. Biomed. Mater. 2018, 82, 257-267. [CrossRef]

8. Ni, G.X.; Chiu, K.Y.; Lu, W.W.; Wang, Y.; Zhang, Y.G.; Hao, L.B.; Li, Z.Y.; Lam, W.M.; Lu, S.B.; Luk, K.D.K. Strontium-containing hydroxyapatite bioactive bone cement in revision hip arthroplasty. Biomaterials 2006, 27, 4348-4355. [CrossRef]

9. De Mori, A.; Di Gregorio, E.; Kao, A.P.; Tozzi, G.; Barbu, E.; Sanghani-Kerai, A.; Draheim, R.R.; Roldo, M. Antibacterial PMMA Composite Cements with Tunable Thermal and Mechanical Properties. ACS Omega 2019, 4, 19664-19675. [CrossRef]

10. Shi, Z.; Neoh, K.G.; Kang, E.T.; Wang, W. Antibacterial and mechanical properties of bone cement impregnated with chitosan nanoparticles. Biomaterials 2006, 27, 2440-2449. [CrossRef]

11. Kowalski, R.; Schmaehling, R. Chapter 6. Commercial aspects and delivery systems of bone cements. In Orthopaedic Bone Cements; Deb, S., Ed.; Woodhead Publishing Limited: Cambridge, UK, 2008; pp. 113-139, ISBN 978-1-84569-517-0.

12. Boesel, L.F.; Cachinho, S.C.P.; Fernandes, M.H.V.; Reis, R.L. The in vitro bioactivity of two novel hydrophilic, partially degradable bone cements. Acta Biomater. 2007, 3, 175-182. [CrossRef] [PubMed] 
13. Khan, A.A.; Mirza, E.H.; Mohamed, B.A.; Alharthi, N.H.; Abdo, H.S.; Javed, R.; Alhur, R.S.; Vallittu, P.K. Physical, mechanical, chemical and thermal properties of nanoscale graphene oxide-poly methylmethacrylate composites. J. Compos. Mater. 2018, 52, 2803-2813. [CrossRef]

14. Lozano, K.; Mina, J.; Zuluaga, F.; Valencia, C.; Valencia, M. Influencia de la incorporación de un co-monómero alcalino e hidroxiapatita en las propiedades de cementos óseos acrílicos. DYNA 2013, 80, 153-162.

15. Espigares, I.; Elvira, C.; Mano, J.F.; Vázquez, B.; San Román, J.; Reis, R.L. New partially degradable and bioactive acrylic bone cements based on starch blends and ceramic fillers. Biomaterials 2002, 23, 1883-1895. [CrossRef]

16. Dalby, M.J.; Di Silvio, L.; Harper, E.J.; Bonfield, W. In vitro evaluation of a new polymethylmethacrylate cement reinforced with hydroxyapatite. J. Mater. Sci. Mater. Med. 1999, 10, 793-796. [CrossRef]

17. Lopes, P.P.; Garcia, M.P.; Fernandes, M.H.; Fernandes, M.H.V. Acrylic formulations containing bioactive and biodegradable fillers to be used as bone cements: Properties and biocompatibility assessment. Mater. Sci. Eng. C 2013, 33, 1289-1299. [CrossRef] [PubMed]

18. Fini, M.; Giavaresi, G.; Nicoli Aldini, N.; Torricelli, P.; Botter, R.; Beruto, D.; Giardino, R. A bone substitute composed of polymethylmethacrylate and $\alpha$-tricalcium phosphate: Results in terms of osteoblast function and bone tissue formation. Biomaterials 2002, 23, 4523-4531. [CrossRef]

19. García-Enriquez, S.; Guadarrama, H.E.R.; Reyes-González, I.; Mendizábal, E.; Jasso-Gastinel, C.F.; García-Enriquez, B.; Rembao-Bojórquez, D.; Pane-Pianese, C. Mechanical performance and in vivo tests of an acrylic bone cement filled with bioactive sepia officinalis cuttlebone. J. Biomater. Sci. Polym. Ed. 2010, 21, 113-125. [CrossRef]

20. He, Q.; Chen, H.; Huang, L.; Dong, J.; Guo, D.; Mao, M.; Kong, L.; Li, Y.; Wu, Z.; Lei, W. Porous Surface Modified Bioactive Bone Cement for Enhanced Bone Bonding. PLoS ONE 2012, 7, e42525. [CrossRef]

21. Lewis, G. Alternative acrylic bone cement formulations for cemented arthroplasties: Present status, key issues, and future prospects. J. Biomed. Mater. Res. B Appl. Biomater. 2008, 84, 301-319. [CrossRef]

22. Rodríguez-Vázquez, M.; Vega-Ruiz, B.; Ramos-Zúñiga, R.; Saldaña-Koppel, D.A.; Quiñones-Olvera, L.F. Chitosan and Its Potential Use as a Scaffold for Tissue Engineering in Regenerative Medicine. Biomed. Res. Int. 2015, 2015, 821279. [CrossRef] [PubMed]

23. Oryan, A.; Sahvieh, S. Effectiveness of chitosan scaffold in skin, bone and cartilage healing. Int. J. Biol. Macromol. 2017, 104, 1003-1011. [CrossRef] [PubMed]

24. Kim, C.H.; Park, S.J.; Yang, D.H.; Chun, H.J. Chitosan for Tissue Engineering. In Advances in Experimental Medicine and Biology; Springer: Singapore, 2018; Volume 1077, pp. 475-485, ISBN 9789811309472.

25. Aguilar, A.; Zein, N.; Harmouch, E.; Hafdi, B.; Bornert, F.; Damien, O.; Clauss, F.; Fioretti, F.; Huck, O.; Benkirane-jessel, N.; et al. Application of Chitosan in Bone and Dental Engineering. Molecules 2019, $24,3009$. [CrossRef] [PubMed]

26. Tamburaci, S.; Tihminlioglu, F. Chitosan-hybrid poss nanocomposites for bone regeneration: The effect of poss nanocage on surface, morphology, structure and in vitro bioactivity. Int. J. Biol. Macromol. 2020, 142, 643-657. [CrossRef] [PubMed]

27. Hamilton, V.; Yuan, Y.; Rigney, D.A.; Chesnutt, B.M.; Puckett, A.D.; Ong, J.L.; Yang, Y.; Haggard, W.O.; Elder, S.H.; Bumgardner, J.D. Bone cell attachment and growth on well-characterized chitosan films. Polym. Int. 2006, 55, 641-647. [CrossRef]

28. Lin, M.C.; Chen, C.C.; Wu, I.T.; Ding, S.J. Enhanced antibacterial activity of calcium silicate-based hybrid cements for bone repair. Mater. Sci. Eng. C 2020, 110, 110727. [CrossRef]

29. Palla-Rubio, B.; Araujo-Gomes, N.; Fernandez-Gutierrez, M.; Rojo, L.; Suay, J.; Gurruchaga, M.; Goni, I. Synthesis and characterization of silica-chitosan hybrid materials as antibacterial coatings for titanium implants. Carbohydr. Polym. 2019, 203, 331-341. [CrossRef]

30. Rojo, L.; Deb, S. Polymer Therapeutics in Relation to Dentistry. Front. Oral Biol. 2015, 17, 13-21. [CrossRef]

31. Valencia Zapata, M.E.; Mina Hernandez, J.H.; Grande Tovar, C.D.; Valencia Llano, C.H.; Diaz Escobar, J.A.; Vázquez-Lasa, B.; San Román, J.; Rojo, L.; Rojo, L. Novel Bioactive and Antibacterial Acrylic Bone Cement Nanocomposites Modified with Graphene Oxide and Chitosan. Int. J. Mol. Sci. 2019, 20, 2938. [CrossRef]

32. Li, Z.; Khun, N.W.; Tang, X.Z.; Liu, E.; Khor, K.A. Mechanical, tribological and biological properties of novel 45S5 Bioglass ${ }^{\circledR}$ composites reinforced with in situ reduced graphene oxide. J. Mech. Behav. Biomed. Mater. 2017, 65, 77-89. [CrossRef] 
33. Kurapati, R.; Bonachera, F.; Russier, J.; Sureshbabu, A.R.; Ménard-Moyon, C.; Kostarelos, K.; Bianco, A. Covalent chemical functionalization enhances the biodegradation of graphene oxide. 2D Mater. 2018, 5, 015020. [CrossRef]

34. Palmieri, V.; Papi, M.; Conti, C.; Ciasca, G.; Maulucci, G.; De Spirito, M.; Palmieri, V.; Papi, M.; Conti, C.; Ciasca, G.; et al. The future development of bacteria fighting medical devices: The role of graphene oxide. Expert Rev. Med. Devices 2016, 13, 1013-1019. [CrossRef]

35. Mirza, E.H.; Khan, A.A.; Al-Khureif, A.A.; Saadaldin, S.A.; Mohamed, B.A.; Fareedi, F.; Khan, M.M.; Alfayez, M.; Al-Fotawi, R.; Vallittu, P.K.; et al. Characterization of osteogenic cells grown over modified graphene-oxide-biostable polymers. Biomed. Mater. 2019, 14, 65004. [CrossRef]

36. Mukherjee, S.P.; Gliga, A.R.; Lazzaretto, B.; Brandner, B.; Fielden, M.; Vogt, C.; Newman, L.; Rodrigues, A.F.; Shao, W.; Fournier, P.M.; et al. Graphene oxide is degraded by neutrophils and the degradation products are non-genotoxic. Nanoscale 2018, 10, 1180-1188. [CrossRef] [PubMed]

37. Girish, C.M.; Sasidharan, A.; Gowd, G.S.; Nair, S.; Koyakutty, M. Confocal raman imaging study showing macrophage mediated biodegradation of graphene in vivo. Adv. Healthc. Mater. 2013, 2, 1489-1500. [CrossRef] [PubMed]

38. Kotchey, G.P.; Allen, B.L.; Vedala, H.; Yanamala, N.; Kapralov, A.A.; Tyurina, Y.Y.; Klein-Seetharaman, J.; Kagan, V.E.; Star, A. The enzymatic oxidation of graphene oxide. ACS Nano 2011, 5, 2098-2108. [CrossRef]

39. Wright, Z.M.; Arnold, A.M.; Holt, B.D.; Eckhart, K.E.; Sydlik, S.A. Functional Graphenic Materials, Graphene Oxide, and Graphene as Scaffolds for Bone Regeneration. Regen. Eng. Transl. Med. 2019, 5, 190-209. [CrossRef]

40. Holt, B.D.; Arnold, A.M.; Sydlik, S.A. In It for the Long Haul: The Cytocompatibility of Aged Graphene Oxide and Its Degradation Products. Adv. Healthc. Mater. 2016, 5, 3056-3066. [CrossRef]

41. International Standard ISO 5833: Implants for Surgery-Acrylic Resin Cements; ISO: Geneva, Switzerland, 2002; pp. 1-22.

42. International Organization for Standardization ISO 10993-6:2016: Biological Evaluation of Medical Devices-Part 6: Tests for Local Effects after Implantation; ISO: Geneva, Switzerland, 2016.

43. Sharma, R.; Kapusetti, G.; Bhong, S.Y.; Roy, P.; Singh, S.K.; Singh, S.; Balavigneswaran, C.K.; Mahato, K.K.; Ray, B.; Maiti, P.; et al. Osteoconductive Amine-Functionalized Graphene-Poly(methyl methacrylate) Bone Cement Composite with Controlled Exothermic Polymerization. Bioconjug. Chem. 2017, 28, 2254-2265. [CrossRef]

44. Paz, E.; Forriol, F.; del Real, J.C.; Dunne, N. Graphene oxide versus graphene for optimisation of PMMA bone cement for orthopaedic applications. Mater. Sci. Eng. C 2017, 77, 1003-1011. [CrossRef]

45. Ormsby, R.W.; Modreanu, M.; Mitchell, C.A.; Dunne, N.J. Carboxyl functionalised MWCNT/polymethyl methacrylate bone cement for orthopaedic applications. J. Biomater. Appl. 2014, 29, 209-221. [CrossRef] [PubMed]

46. Gonalves, G.; Cruz, S.M.A.; Ramalho, A.; Grácio, J.; Marques, P.A.A.P. Graphene oxide versus functionalized carbon nanotubes as a reinforcing agent in a PMMA/HA bone cement. Nanoscale 2012, 4, 2937-2945. [CrossRef] [PubMed]

47. Lin, L.; Chang, S.; Kuo, S.M.; Chen, S.H.U.F.E.N. Evaluation of chitosan/ $\beta$-tricalcium phosphate microspheres as a constituent to PMMA cement. J. Mater. Sci. Mater. Med. 2005, 16, 567-574. [CrossRef] [PubMed]

48. Zamora Lagos, S.I.; Murillo Salas, J.; Valencia Zapata, M.E.; Mina Hernandez, J.H.; Valencia, C.H.; Rojo, L.; Grande Tovar, C.D. Influence of the chitosan morphology on the properties of acrylic cements and their biocompatibility. RSC Adv. 2020, 10, 31156-31164. [CrossRef]

49. Ruiz, S.; Tamayo, J.A.; Ospina, J.D.; Navia Porras, D.P.; Valencia Zapata, M.E.; Mina Hernandez, J.H.; Valencia, C.H.; Zuluaga, F.; Grande Tovar, C.D. Antimicrobial Films Based on Nanocomposites of Chitosan/Poly (vinyl alcohol)/Graphene Oxide for Biomedical Applications. Biomolecules 2019, 9, 109. [CrossRef]

50. Valencia, C.; Valencia, C.; Zuluaga, F.; Valencia, M.; Mina, J.; Grande-Tovar, C. Synthesis and Application of Scaffolds of Chitosan-Graphene Oxide by the Freeze-Drying Method for Tissue Regeneration. Molecules 2018, 23, 2651. [CrossRef]

51. Tavakoli, M.; Bakhtiari, S.S.E.; Karbasi, S. Incorporation of chitosan/graphene oxide nanocomposite in to the PMMA bone cement: Physical, mechanical and biological evaluation. Int. J. Biol. Macromol. 2020, 149, 783-793. [CrossRef] 
52. Moon, C.; Seo, D.J.; Song, Y.S.; Jung, W.J. Antibacterial activity of various chitosan forms against Xanthomonas axonopodis pv. glycines. Int. J. Biol. Macromol. 2020, 156, 1600-1605. [CrossRef]

53. Maleki Dizaj, S.; Mennati, A.; Jafari, S.; Khezri, K.; Adibkia, K. Antimicrobial activity of carbon-based nanoparticles. Adv. Pharm. Bull. 2015, 5, 19-23. [CrossRef]

54. Akhavan, O.; Ghaderi, E. Toxicity of graphene and graphene oxide nanowalls against bacteria. ACS Nano 2010, 4, 5731-5736. [CrossRef]

55. Gurunathan, S.; Han, J.W.; Abdal Dayem, A.; Eppakayala, V.; Kim, J.H. Oxidative stress-mediated antibacterial activity of graphene oxide and reduced graphene oxide in Pseudomonas aeruginosa. Int. J. Nanomed. 2012, 7, 5901-5914. [CrossRef] [PubMed]

56. Mangadlao, J.D.; Santos, C.M.; Felipe, M.J.L.; de Leon, A.C.C.; Rodrigues, D.F.; Advincula, R.C. On the antibacterial mechanism of graphene oxide (GO) Langmuir-Blodgett films. Chem. Commun. 2015, 51, 2886-2889. [CrossRef] [PubMed]

57. Liu, S.; Zeng, T.H.; Hofmann, M.; Burcombe, E.; Wei, J.; Jiang, R.; Kong, J.; Chen, Y. Antibacterial activity of graphite, graphite oxide, graphene oxide, and reduced graphene oxide: Membrane and oxidative stress. ACS Nano 2011, 5, 6971-6980. [CrossRef] [PubMed]

58. Chen, J.; Peng, H.; Wang, X.; Shao, F.; Yuan, Z.; Han, H. Graphene oxide exhibits broad-spectrum antimicrobial activity against bacterial phytopathogens and fungal conidia by intertwining and membrane perturbation. Nanoscale 2014, 6, 1879-1889. [CrossRef]

59. Ahmed, S.; Annu; Ali, A.; Sheikh, J. A review on chitosan centred scaffolds and their applications in tissue engineering. Int. J. Biol. Macromol. 2018, 116, 849-862. [CrossRef]

60. Khandaker, M.; Vaughan, M.B.; Morris, T.L.; White, J.J.; Meng, Z. Effect of additive particles on mechanical, thermal, and cell functioning properties of poly(methyl methacrylate) cement. Int. J. Nanomed. 2014, 9, 2699-2712. [CrossRef]

61. Richards, R.G. The effect of surface roughness on fibroblast adhesion in vitro. Injury 1996, 27, S/C38-S/C43. [CrossRef]

62. Wirth, C.; Comte, V.; Lagneau, C.; Exbrayat, P.; Lissac, M.; Jaffrezic-Renault, N.; Ponsonnet, L. Nitinol surface roughness modulates in vitro cell response: A comparison between fibroblasts and osteoblasts. Mater. Sci. Eng. C 2005, 25, 51-60. [CrossRef]

63. Zhang, M.; Zhang, Z.; Ding, N.; Zheng, D. Effect of airborne-particle abrasion of presintered zirconia on surface roughness and bacterial adhesion. J. Prosthet. Dent. 2015, 113, 448-452. [CrossRef]

64. Rosqvist, E.; Niemelä, E.; Venu, A.P.; Kummala, R.; Ihalainen, P.; Toivakka, M.; Eriksson, J.E.; Peltonen, J. Human dermal fibroblast proliferation controlled by surface roughness of two-component nanostructured latex polymer coatings. Colloids Surf. B Biointerfaces 2019, 174, 136-144. [CrossRef]

65. Andrukhov, O.; Behm, C.; Blufstein, A.; Wehner, C.; Gahn, J.; Pippenger, B.; Wagner, R.; Rausch-Fan, X. Effect of implant surface material and roughness to the susceptibility of primary gingival fibroblasts to inflammatory stimuli. Dent. Mater. 2020, 36, e194-e205. [CrossRef]

66. Anderson, J.M.; Rodriguez, A.; Chang, D.T. Foreign body reaction to biomaterials. Semin. Immunol. 2008, 20, 86-100. [CrossRef]

67. Maiborodin, I.V.; Shevela, A.I.; Morozov, V.V.; Novikova, Y.V.; Matveeva, V.A.; Drovosekov, M.N.; Barannik, M.I. Reaction of the rat tissues to implantation of polyhydroxyalkanoate films and ultrafine fibers. Bull. Exp. Biol. Med. 2013, 154, 379-384. [CrossRef]

68. Lorenz, J.; Barbeck, M.; Sader, R.A.; Kirkpatrick, C.J.; Russe, P.; Choukroun, J.; Ghanaati, S. Foreign Body Giant Cell-Related Encapsulation of a Synthetic Material Three Years after Augmentation. J. Oral Implantol. 2016, 42, 273-277. [CrossRef]

(C) 2020 by the authors. Licensee MDPI, Basel, Switzerland. This article is an open access article distributed under the terms and conditions of the Creative Commons Attribution (CC BY) license (http://creativecommons.org/licenses/by/4.0/). 